\title{
Politicised Compassion and Pedagogical Partnership: A Discourse and Practice for Social Justice in the Inclusive Academy
}

\author{
*Dr. Suanne Gibson, Plymouth Institute of Education, Plymouth University, UK \\ Dr. Alison Cook-Sather, Education Program, Bryn Mawr College, USA
}

Contact: s1gibson@plymouth.ac.uk

\section{ABSTRACT}

Despite changes prompted by global legalisation and policy developments for social justice and inclusion, many institutions of higher education remain driven by neoliberal values, an endemic culture of performativity, and an emphasis on individual success. These phenomena inform, disfigure, and invert inclusion and equality in policy, practice, and outcome. In response, we propose politicised compassion fostered through pedagogical partnership as a political and social justice reaction to the status quo. This paper explores this proposal, grounding it in international research studies on student experience, partnership, and equality. The work's novelty is in its advancement of Zembylas' (2013) work on "critical compassion" through what we term politicised compassion with the goal of enabling sustained student agency, student success, and the creation of active, considerate citizens. Our work invites critical considerations of where such a discourse for meaningful social justice and equality can take place within the academy.

KEYWORDS

politicised compassion, pedagogical partnership, social justice, equality, student experience

Although global legalisation and policy developments for social justice and inclusion have proliferated in recent years, these are in tension in many Western contexts with shifts to the right in government and wider society, increasing intolerance of the "other," the reinforcing of structural inequalities, and the impact of long-term economic and structural woes upon the poor and oppressed. This tension plays out in colleges and universities (Cook-Sather, Des-Ogugua, \& Bahti, 2018; Gibson, 2015; Gibson et al., 2018), which are microcosms of the societies in which they are situated. Alongside other efforts that strive for inclusivity and equity in higher education (Bracken \& Novak, 2019; Burke, Bennett, Burgess, Gray, \& Southgate, 2016), politicised academics working in partnership with politicised students can be key to countering systemic inequality and to pursuing justice. We argue for a process of "politicisation" of education and the need for a collaborative 
discourse that leads to and supports what we have termed politicised compassion. We propose that pedagogical partnership between faculty and students is a space within which politicised compassion can be developed as a discourse and a practice for meaningful social justice and equity.

\section{CONTEXT: INCLUSION, DIVERSITY, AND SOCIAL JUSTICE IN HIGHER EDUCATION}

Internationally, higher education has enacted significant changes to its practices and goals in keeping with global legalisation and policy developments for social justice and inclusion. There has been much debate about the worth and impact of initiatives such as "Widening Participation" in the UK (Burke, 2012; Department for Education and Skills [DfES], 2003; DfES, 2004; Gale \& Hodge, 2014; Gibson, 2015) and a commitment by the U.S. Department of Education (2016) to create diverse and welcoming campus communities for all students. These initiatives have generally been credited with increasing numbers of higher education (HE) students who were previously excluded (e.g., disabled students, ethnic minorities, "mature" learners, working class students, and "first-in-the-family" students). However, significant under-representation of these groups continues. Studies have asserted claims of discrimination against disabled students, also known as "disablism," and practices of covert discrimination are perpetuated due to a lack of understanding of or critical engagement with how and where discrimination exists in the sector (Madriaga, 2007; Ahmed \& Swain, 2006; Burke, 2012; Beauchamp-Pryor, 2012; Gibson et al., 2016).

The term "inclusion" in education has been redefined, repackaged, and rebranded (Gibson, 2006; Gibson \& Kendall, 2010; Gibson, 2015), its definition determined by the dominant political agency of the day. Its original meaning was grounded in human rights and equality as captured in the work of Oliver and Zarb (1989), Barnes and Oliver (2010), Allan (2015), and others. Once colonised by the establishment, the term lost its original ideals, and radical change for social justice became overshadowed by bureaucratic wrangling and debates about resource allocation. Gibson (2015) highlights this development in her work with disabled students where "the world of many 'included' disabled students is one of trial and error, frustration and failure" (p. 875). This misunderstanding and redefining by policy makers and institutions has resulted in the loss of inclusion's original critical and political stance, as once defined by those who continue to live with exclusion and oppression (Madriaga, 2007; Madriaga, Hanson, Kay, \& Walker, 2011; Quinn, 2013; Liasidou, 2014; Gibson, 2015).

Hockings (2010) articulates what inclusive education (IE) means in relation to HE and how it is deeply connected to ideas regarding social justice as opposed to mere "welfare" approaches to teaching and learning for students who are positioned by the dominant culture as lacking the capacity to succeed at university. She argues:

Inclusive learning and teaching in higher education refers to the ways in which pedagogy, curricula and assessment are designed and delivered to engage students in learning that is meaningful, relevant and accessible to all. It embraces a view of the individual and individual difference as the source of diversity that can enrich the lives and learning of others.

As Cook-Sather (2015, p. 5) notes, we can conceive of difference "as constituting unbridgeable divides among us," or we can let it "inspire respect and empathy" and serve as 
"a basis for developing connections and as a resource for learning and growth." We argue that inclusive education should do the latter and that it is about creating an equally transformative educational experience for all our students by taking into consideration and valuing their various identities and intersections.

This work connects to the field of "diversity" and what that means in relation to identity, both self-selected and externally imposed. We critically consider how institutionalised and policy-driven definitions of diversity are contributing to inequality through their pathologising of "difference." ARC (2013) clarifies who is being referred to when policy specifies diverse student groups: "Widening participation students' are not a homogeneous group. ... [They include] people from lower socio-economic groups, mature students, part-time learners, learners from ethnic minority groups, vocational and workbased learners, disabled learners, and care leavers" (p. ii).

Thus diversity refers to those traditionally excluded from $\mathrm{HE}$, and positions many aspects of identity as external to the "norm," which has negative results. For example, Madriaga et al. (2011) argue: "Normalcy heralds a nondisabled person without 'defects,' or impairments, as the ideal norm. ... this sense of normalcy reproduces thinking that nontraditional students are non-white, working class and/or disabled" (p. 901). This reproduction of "normalcy" and "non-traditional" creates a culture where HE institutions continue to marginalise and suppress those who seek equality and academic success (Slee, 2008; Madriaga et al., 2011).

The widening scope of IE from questions of disability to those of diversity and other intersectionalities has, according to Slee (2008), "softened and subverted" IE's claims (p. 100). Ahmed and Swain (2006) also critique the "softening" of language, arguing that the label "diversity" "individuates difference, conceals inequalities and neutralises histories of antagonism and struggle" (p. 96). Intersectionality, on the other hand, underscores the "'multidimensionality' of marginalized subjects' lived experiences (Crenshaw, 1989: 139)" (Nash, 2008, p. 1) and "highlights the need to account for multiple grounds of identity when considering how the social world is constructed" (Crenshaw, 1991, p. 1245). Indeed, "social inequality is not only determined multidimensionally along different axes of inequalitysuch as gender, migration, socioeconomic background, age, disability, and so on-but emerges particularly in the intersection of these axes as they mutually constitute each other within social contexts" (Gross, Gottburgsen, \& Phoenix, 2016, p. 51).

In current HE practices, much discussion of inclusive education centres around the establishment's creation of "diverse" student identity, where their academic needs are assessed and considered as "other" in relation to the established norm and where policy discourse refers to such students as non-traditional. The language glosses over differences in ways that divert attention from inequalities, thereby re-producing divisions and reinforcing insiders and outsiders. It is important to note the complexities and tensions involved when attempting to locate, define, or label groups of people. Labelling can be an ostracizing activity, creating and then reinforcing a person's or people's externally imposed excluded form.

Whilst international undergraduate prospectuses and university websites make it appear that HE successfully includes many diverse students, looking deeper, we see that this is not always the case. With high dropout rates, university transfers, negative student feedback, stories of frustration and failure (Beauchamp-Pryor, 2012; Gibson, 2012; Quinn, 2013), the world of many "included" students is one of trial, error, and failure rather than 
growth and academic success. Noting HE's history (i.e., historically who had access and who did not), Hughes (2015) wonders "whether contemporary universities are capable of righting social wrongs at all" (p. 304). Related to this point, Gibson (2015) draws on Bourdieu's theory of habitus - that institutional habitus, through habits of mind and practice, result in a form of institutional agency, which maintains the disenfranchisement and exclusion of "other" - to explore the nuanced ways in which traditional thinking and established norms continue to exclude the "diverse" student.

Other critiques inform a critical analysis of international HE "socially just" practices and positions. Giroux (2010), drawing on the work of Agamben (1998), argues that the main driving force behind $\mathrm{HE}$ and education in general is neoliberalism, not social justice. He maintains that

we are witnessing the emergence and dominance of a form of bare pedagogy and the construction of a new kind of market-driven individual. It places an emphasis on winning at all costs, a ruthless competitiveness, hedonism, the cult of individualism. . . Within this pedagogy, compassion is a weakness, and moral responsibility is scorned because it places human needs over market considerations. (Giroux, 2010, p. 185)

In a similar critique of recent developments through which universities have been turned into "enterprises serving the market," Grummell, Devine, and Lynch (2009) argue that such neoliberal practices result in the culling of compassion and the creation of a culture where an indifference to the affective domain of learning and the emotional subject is commonplace (p. 191).

Inclusion and its original social-justice driver are being suffocated by this neoliberal discourse. Debates, political and historical stories around equality, and humanity are repositioned in the more digestible language of diversity, not in the articulation of unethical, unjust, unequal, or oppressive histories and their continuation. Thus, by creating policy and practice from within such a constrained position, the academy is merely re-creating, controlling, and containing various student bodies within a dominant and unproblematized structure (Fleras, 2011). Walker (2010) makes a strong case for a radical change to what informs the academy-where it finds its rationale, what its key purpose is - by arguing that HE's rationale has for too long made an incorrect assumption: that economic growth and human development mean the same thing. The work of Gale and Hodge (2014), alongside that of others (Quinn, 2013; Gibson, 2015), makes clear that education and social justice in the university are imaginary due to their being overshadowed... by a dominant neoliberal discourse (Gale \& Hodge, 2014).

This overview of how and why practices of institutionalised inclusion and equality are failing provides the context for our idea of politicised compassion through pedagogical partnership. Contemporary research suggests continued inequality within HE due to the dominant neoliberal driver of profit, unproblematized approaches to inclusion, and the continued pathologising and re-positioning of minority groups as "other." Seeking a way forward by critically considering compassion as a part of the educator's role in $\mathrm{HE}$, in the next section of our discussion we define politicised compassion and draw on student experiences and analyses from previous research studies to further argue for its necessity. Our goal is not to contend that all students experience the same forms of pathologising and 
othering, which would be antithetical to our overall argument. Rather, we share students' individual experiences, which might or might not be the same as other students' experiences, in order to name issues that all should consider.

\section{DEFINING POLITICISED COMPASSION: A DISCOURSE FOR A RENEWED COMMITMENT TO SOCIAL JUSTICE IN EDUCATION}

It would be ill considered to suggest faculty work without holding their students as humans in their thoughts and pedagogical practices. Likewise, it would be unfair to argue educators in HE function without a sense of compassion for each other, their students, and themselves. However, in our neoliberal spaces that encourage enacting performativity rather than attending to the actions and thoughts of people, such positions are becoming more and more difficult to maintain and increasingly untenable in terms of impact (Lynch, 2010; Gibson \& Baskerville, 2017). In this section of our discussion we consider what a political discourse focused on socially just and compassionate pedagogy might look like.

Compassion, as a state of being, entails an emotional reaction to something or someone. This reaction is tied to feelings of empathy and may result in a state of action. Warwick (2016) takes a moral perspective on compassion, exploring the places and need for civic compassion in his work on education for sustainable development (ESD). Writing about the need for "kinder learning spaces," he articulates the necessity of a curriculum that supports students in understanding themselves and others through developing an "ethic of compassionate concern for well-being and the common good" (Warwick, 2016, p. 408). Complementing this civic compassion, Rashedi, Plante, \& Callister (2015) emphasise action; compassion "extends beyond merely feeling concern for others. ... [It] is an action-oriented affective state ... [that] requires one's strength to be with the suffering" (p. 132).

Zembylas (2013) discerns a crisis in relation to practices of uncritical compassion that encourage student and faculty positions of pity, objectification, paternalism, and voyeurism from where no significant action can take place. He states: "pity retains the asymmetry between the spectator and the sufferer and downplays the existing power differentials and inequalities" (Zembylas, 2013, p. 507). This discourse of pity, Zembylas (2013) maintains, results in "feeling sorry about those who suffer without necessarily taking action to alleviate the structural conditions and effects of suffering" (p. 506). He argues for incorporating a politics of compassion into the work of critical educators that acknowledges what and where structural inequalities exist and challenges privileged irresponsibility.

Students can offer individual and collective insight into their lived and observed experiences with inequality. Their analyses provide richly layered and nuanced interpretations of structural and cultural barriers to inclusion. These analyses, when given a platform and valued by the academy, provide both the substance and the catalyst for politicising compassion-a form of compassion that results in a notable change to university/wider societal practices and related student experience. Through engaging with these student analyses, we see how, where, and why significant inequality in our university and wider society continues.

For instance, students who participated in two studies-an international study with undergraduate students from Cyprus, New Zealand, the United States (US), and the United Kingdom (UK) (Gibson et al., 2017), and a smaller-scale study with undergraduate students in one university in the southwest of England (Gibson, Grace, O'Sullivan, \& Pritchard, 2018)highlight the struggles and challenges that our included and institutionally positioned 
"diverse" students' experience. One is stereotyping, as one UK student asserts (Gibson et al., 2017, p.17): "I think diversity creates stereotypes -it's still labelling and not celebrating it or letting it just be." A student from the US concurs (Gibson et al., 2017, p.17): "I guess with my diversity, it doesn't make me who I am and there are a lot of things that make me who I am, not just that one thing. Like, that doesn't define me .. . like stereotypes." Two other students highlight how othering happens through labelling when they come to university-how it is, in fact, a function of coming to university. As one student from New Zealand explained (Gibson et al., 2017, p.18): "Well I've always thought of myself as normal until coming to university because I am 'mature student,' 'solo parent' and I've had 'dyslexia.' So until starting university I was just, this is what I was." A student from the US distinguishes between describing oneself and being labelled by others (Gibson et al., 2017, p.18): "It feels okay to label yourself because that is within your choice and control, but it doesn't feel so good when someone else labels you." These excerpts of student analyses provide critical insights regarding matters of language, labelling, and how institutional practices position and stereotype in ways that are not experienced as helpful or inclusive-in fact, quite the opposite.

Other student analyses highlight that knowledge is power and show education failing to provide important knowledge to students, thus hindering their experience and reinforcing their lesser-valued position. As one student from Cyprus put it (Gibson et al., 2017, p.21): "Some of us don't know our rights, and therefore we don't ask for them." Another student explained that, even when students try to access knowledge and support, they are often thwarted (Gibson et al., 2017, p.21) : "Basically, we need to feel that we belong in this university, ... communication should be easier. I should not send ten emails and go to the Students' Welfare Department ten times in order to be assisted." Alongside this are stories of departmental failures in communication and related practitioner/tutor preparedness. Another student from Cyprus explained (Gibson et al., 2017, p.19): "I'm embarrassed to go ask for extra time. Sometimes I ask, but once, a teacher asked me for a proof. I don't like this."

These analyses show where and how injustice and exclusion continue to operate. They reveal where students have experienced a lack of compassion and understanding through their external positioning within institutional policy discourse and, subsequently, because of ongoing structural inequality, continue to experience exclusion. These examples highlight how the academy, whilst seemingly working for inclusion, pathologises those it positions as diverse or "deserving other" and functions without a political understanding of a student's own position and/or life experience.

Zembylas (2013) argues that critical compassion is cultivated "when we begin to understand the conditions (structural inequalities, poverty, globalization, etc.) that give rise to suffering and acknowledge some sort of human connection" (p. 516). What needs to follow this dawning understanding, he argues, "is taking action that dismisses essentialized categories of victims and benefactors and highlights instead the impact of solidarity on reducing everyday inequalities" (p. 516). Zemblyas' (2013) call for solidarity and his proposal for pedagogies of critical compassion provide a framework for considering a meaningful response to contemporary injustices in education and wider global matters of inequality. Our work responds to this call for action; it argues for solidarity amongst faculty and students and for moving beyond holding a critical position on what compassion is. Our idea of politicised compassion is a political position that encourages practical action framed within the wider critical work of social justice and equality. 
Solidarity and discourse within, between, and across parties of student and faculty are key to realising a discourse of politicised compassion in higher education. The need to ask difficult questions and engage in challenging discussions about social injustice regarding how it becomes manifest and is re-created through institutionalised and wider social positions and practices are central to PC. Politicised compassion works in response to Zembylas' critique of essentialised categories of "other" (e.g., "non-traditional/diverse student," "ethnic minority," "disabled," "poor"). In holding a PC position, we can deconstruct essentialised categories and explore their origins and histories in relation to positions of power (i.e., who has power and what authority and questions of agency are considered). PC enables students, faculty, and connected advocates to see the existence of inequality within a complex array of structural and human constraints that result in practices and positioning that prevent the development of agency, thereby recreating dependency, paternalism, and exclusion. Thus, PC is an action-oriented, critical, and collective response of solidarity to the status quo of neoliberalism, exclusion, and micro and macro forms of inequality as and where they exist. The question is where and how to position this discourse such that it enables the change it aspires to create.

In the next section, we link this active and political form of compassion to partnership practice between faculty and students, offering this discourse and practice for equity as a forum and platform for change in challenging times.

\section{LOCATING A SPACE FOR POLITICISED COMPASSION WITHIN PEDAGOGICAL PARTNERSHIP PRACTICES}

Politicised compassion requires engagement, commitment, and social action. The fear and uncertainty fostered by the current political climate, fuelled by performativity pressures, promote instead distrust and alienation. The hierarchical audit culture requires academics to monitor each other: "Workplace collegiality and responsibility are threatened by the way in which the top-down surveillance ... is matched by lateral surveillance as we not only begin to responsibly monitor ourselves but also our peers and colleagues" (Cupples \& Pawson, 2012, p. 18, quoted in Mutche \& Tatbe, 2017, p. 228). The fear and selfmonitoring students experience likewise leads to alienation. As Bovill (2017) explains: "in many instances, students' alienation is an understandable and logical response to the conditions they find themselves in, within the higher education context" (p. 15).

Pedagogical partnerships strive to create the conditions Mann (2001) proposes as counter-responses to alienation: "solidarity; hospitality; providing safety; redistribution of power; criticality" (p. 15, quoted in Bovill, 2017)-as well as compassion. Pedagogical partnerships support students and faculty in embracing the vulnerability and transformative potential of collaborative work focused on working toward more equitable and inclusive practices. They do not automatically do so, however; some students do not feel that they can participate in partnership efforts (Marquis, Jayaratnam, Mishra, \& Rybkina, 2018), and not all partnership experiences are empowering (Healey, Lerczak, Welsh, \& France, 2019). But if structured intentionally, pedagogical partnerships can support meaningful dialogue that breaks down traditional barriers between instructors and students; affirm students' knowledge and capacities and increase their confidence; and support the transformation of faculty teaching practices, which can begin to transform the culture of the institution (CookSather \& Agu, 2013; Cook-Sather et al., 2019; de Bie, Marquis, Cook-Sather, \& Luqueño, 2019). Many partnership programs also compensate students with pay, which many 
students need to earn to be at university, for work that is meaningful and dignified (Jack, 2019). For these reasons, partnerships have the potential, as we discuss below, to nurture the development of politicised compassion.

Cook-Sather, Bovill, and Felten (2014) define pedagogical partnership as "a collaborative, reciprocal process through which all participants have the opportunity to contribute equally, although not necessarily in the same ways, to curricular or pedagogical conceptualization, decision making, implementation, investigation, or analysis" (pp. 6-7). When such collaborative work focuses on both surfacing and addressing the structural inequities that make engagement and success in higher education more accessible and attainable for some students and less so for others, it promotes solidarity, offers hospitality, provides safety, and redistributes power, and it does so with a criticality that promotes politicised compassion. Such programs have been developed at small and large, selective and comprehensive, well-funded and under resourced $\mathrm{HE}$ institutions in more than 11 countries (Cook-Sather, Bahti, \& Ntem, 2019) and can take the form of stand-alone programs, be part of teaching and learning centres, or be folded into other existing institutional structures (e.g., work-study).

Seeing the possibility of imaginary social justice is the first step in becoming politicised. Once faculty see students' experiences more clearly and learn from students' analyses of their experiences, and once students experience being seen and listened to as well as learn to see and listen to other students, this political awareness can spark further dialogue and action. Moving beyond the imaginary (Gale \& Hodge, 2014), such work has the potential to produce new meaningful practice for social inclusion.

Pedagogical partnership affords students and faculty opportunities to name and address inequitable and exclusive practices from multiple perspectives. Certainly the different institutional roles of faculty and students provide different perspectives, but partnership work is also informed by the multiple dimensions of identity each person brings to those roles-the experiences, causes, and potential ways of addressing how differences in cultural capital, gender, ability, race, and more position students and faculty differently in higher education. Once students and faculty are more aware of the lived experiences of others in those roles, they can develop both agency and commitment not only in regards to deconstructing essentialised categories (e.g., who has power) but also in regards to working against those categories.

Partnership "gives primacy to processes of dialogue and negotiation in teaching and learning grounded in the principles of mutual respect and inclusivity" (Matthews et al., 2019). Drawing on three key guiding principles that underlie partnership-respect, reciprocity, and shared responsibility (Cook-Sather et al., 2014, p. 175), as well as trust, courage, plurality, authenticity, honesty, inclusivity, and empowerment (Healey, Flint, \& Harrington, 2014, pp. 14-15)-partnership is enacted within "an ethic of reciprocity": a "process of balanced give-and-take not of commodities but rather of contributions: perspectives, insights, forms of participation" (Cook-Sather \& Felten, 2017, p. 181). Among the markers of meaningful student-faculty partnership work are that it fosters inclusive collaborations and nurtures power-sharing relationships through dialogue and reflection (Matthews, 2017). All of these constitute and can inform a politicised compassion through which both faculty and students recognise or deepen their understanding of inequities and forms of exclusion and, rather than simply regret them, which compassion alone certainly allows, actively work together to address them. 
This work connects to what Zembylas (2013, p.504) has called "critical pedagogies of compassion": the pedagogies that engage students and educators in a critical interrogation of the intersections among power, emotion, and praxis in society and education. Such pedagogies in higher education can be "regarded as practices of care that encourage students and educators to be attentive to their own emotional positions with regard to caring responsibilities and privileged irresponsibilities" (Zemblyas, Bozalek, \& Shefer, 2014, p. 210). This links to the counter-responses that Mann (2001) identifies in the current conditions of higher education. Student-faculty pedagogical partnerships both enact and support critical pedagogies of emotion. They create redefined "counter spaces" (Solórzano, Ceja, \& Yosso, 2000) where differences of all kinds, when engaged with compassion and reverence, can become resources for developing greater empathy and respect (Cook-Sather, 2015; Cook-Sather \& Agu, 2013) and can inform intentional action to redress inequities (de Bie, Marquis, Cook-Sather, \& Luqueño, 2019; Mercer-Mapstone, Islam, \& Reid, 2019).

Our interest is how contemporary forms of pedagogical partnership can bring considered forms of politicised compassion into partnerships themselves, into the classroom practices that partnership support, and beyond partnerships. Specifically, we see compassion as a political response to the status quo of neoliberalism, hegemony, exclusion, and Zembylas' concern regarding pity and narcissism - the mindset students and faculty can fall back into, or the more distanced and passive state of pity in which they focus only on their own experiences, not on those of others. Through political forms of compassion, we can see with our students the realities of where exclusion and oppression take place, how inequality takes form, and where power is held, and we can challenge practices of pity and enable a learning outcome and an understanding that is transformational for the learner-and, often, the teacher.

There is a growing sense of awareness amongst the student body that individual responsibility and political activism, stemming from a connection with the oppressed, which may include the students, and their stories, is a way forward. The perspectives we include in this section of our discussion were offered by students and faculty over a decade during which students have been raising questions, engaging in protests (Jaschick, 2016), expressing "renewed interest in civic and political engagement," and engaging in more activism (New, 2016) on college and university campuses. These are responses to the long legacies of discrimination and structural inequality that have impacted students' identification with and sense of inclusion in or exclusion from the institutions they attend (Cook-Sather et al., 2018). As with many of the protests in the 1960s and 1970s, the current wave of student protest in the US, as well as in New Zealand, Australia, South Africa, and Europe, "has been generated by, and is entwined with, national concerns, particularly racism, sexual violence, and growing inequality" (Volk, 2017).

The quotes from students and faculty below suggest that pedagogical partnerships inside HE enable students and faculty to engage and fight structural inequalities both inside and outside the academy. As we note earlier in our discussion, we do not mean to suggest that the students we quote experience the same forms of pathologising and othering as other students or that their perspectives on and experiences of partnership are uniform or universally shared. Instead, we offer excerpts that capture the underlying and sometimes explicit themes that have surfaced across multiple studies of student partners' experiences. Although the students who attend these HE institutions and some of the faculty with whom they work might be marginalised in various ways, they are still relatively privileged members of society, and they can use that privileged position to engage in activism. 
We illustrate this possibility through several examples. These examples demonstrate how the pedagogical partnership program that the second author of this discussion, Alison, has directed for 13 years provides a forum within which faculty and students can engage in listening, attending, caring for, and learning from and with one another. In these activities participants are guided by a "radical collegiality" that "embraces difference as an important source of practical energy and intellectual creativity" (Fielding, 1999, p. 24). This partnership program, called Students as Learners and Teachers (SaLT), is based at Bryn Mawr and Haverford Colleges in the United States. It pairs undergraduate students and faculty in semester-long, one-on-one partnerships focused on co-creating equitable and inclusive pedagogies (CookSather, 2018a). SaLT pays student partners by the hour for their work (Jack, 2019) or provides an independent study through which they can earn course credit. It strives to support faculty and students as they "dance with the cultures of difference in order to explore the possibilities of a meaningful pedagogy for inclusion" (Gibson, 2015, p. 883).

The excerpts in this section of our discussion are drawn from ethics-board approved research studies of student and faculty experiences of participating in SaLT (in which case they have no citation) or from published essays and articles on this work (in which case they include citations). These excerpts illustrate how students and faculty come to awareness and begin to take action, embracing their own identities and advocating for those with a range of "othered" identities. The space for politicised compassion in pedagogical partnership in SaLT is created through mutually informing conversations - weekly classroom observations the student partners conduct in their faculty partners' classrooms, weekly meetings of the pairs of student and faculty partners, and weekly meetings Alison holds with groups of student partners (CookSather, 2018a, 2016). In these spaces, student and faculty partners develop language to name experience and develop approaches to addressing inequities (Cook-Sather, 2019).

Through participating in partnership through SaLT, student partners assert that they develop not only awareness but also a sense of legitimacy, capacity, and responsibility. This outcome is particularly important for students who have been othered. In contrast to the students we quoted in the section of our discussion above called "Defining Politicised Compassion," who described being stereotyped and labelled, students in SaLT regularly offer comments such as this one:

I was more aware of my own identity and my own experiences and what I can contribute. I think I felt stronger and more empowered to give my voice. I felt like I had more to contribute in my own classes and just talking to students. (Quoted in de Bie et al., 2019, p. 44)

The development of such awareness and empowerment contrasts sharply with the experience of being stereotyped and labelled.

When students with more privilege participate in partnership, they develop a different kind of awareness, capacity, and sense of responsibility. Another student who participated in SaLT asserted: "my awareness of my privilege made me reflect on inequity in those [classroom] spaces that we were in. So I worked really hard to bring that into all of my partnerships." She explained: "I tried to make space for faculty to see that my experience as a student is not the universal experience of the student." Similarly, another student who experiences multiple forms of privilege explained: 
It helped me be kind of a better citizen in the classroom ... [and] got me started thinking about how students can be better advocates in those spaces and include one another and create more of a sense of community and shared endeavor in the classroom. (Quoted in Cook-Sather, 2018b, p. 928).

Through the classroom observations and the weekly meetings that constitute SaLT, student partners name their own experiences and develop much greater awareness of others' experiences as those unfold within inequitable institutional structures. As one student partner explained:

You are trying to think about how structures of power are working all the time, so that has a huge influence in a classroom in thinking about whose voices are getting heard and how often and how is the content of the class landing with people of different identities. (Quoted in Cook-Sather, 2019)

This naming and raised awareness carry as a form of politicised compassion beyond the partnerships and into students' own classrooms. For instance, one student partner explained: "I started to think of myself more as an advocate within classroom spaces for my peers. I began to feel I had a lot more agency and could be an agent of change within my classroom spaces" (quoted in Cook-Sather, 2018b, p. 929). Another student asserted that working in the role of student partner reinforced for her that "not only did my perspective, assessment skills and commitment to make spaces safer for underrepresented groups deeply matter-they could drive important transformation in classrooms and in the student-teacher relationship" (Cook-Sather \& Agu, 2013, pp. 277-278). Experiences of partnership, student partners consistently argue, prompt students, even after they graduate, "to voice [their] discontentment towards situations that [they] felt were unethical or culturally insensitive instead of merely being a silent witness" (student quoted in CookSather \& Agu, 2012).

Just like student partners, faculty partners can develop a sense of politicised compassion through their partnership work. One faculty partner explained how working in partnership with a student from an underrepresented group "widened my interpretations and often cleared the way for me to listen and see more sensitively and with expanded or adjusted context in subsequent classes" (quoted in Cook-Sather, 2019). As we note above, seeing the possibility of imaginary social justice is the first step in becoming politicised. The listening, expanding, and adjusting this faculty member describes are first steps.

Faculty also describe developing the language to name and address inequities in their classrooms. For instance, one faculty member explained:

[Working in partnership with a student partner of color allowed me] to speak more openly and frankly about race. [My student partner offered] suggestions for how to redirect the conversation, how to call out students, or how to support other students in the class to contest [racist] views. (Quoted in Cook-Sather \& Agu, 2013, p. 279)

Faculty who are themselves underrepresented in HE suggest that working in partnership with students both affirms their identities and supports them in taking action. 
One faculty member, who self-identifies as "a mixed-race White and Hispanic woman from a low-income urban area" (Perez, 2016), wrote that her partnership with a student, also an underrepresented minority in $\mathrm{HE}$, was "essential for developing the brave space necessary to have these conversations, validating how my personal experiences influence my teaching, and supporting the changes I attempt to make" (Perez, 2016). This faculty member both talked with students enrolled on her courses about inequities and injustices in the natural sciences and also wrote an essay about her efforts to model challenging such injustices and to reach a wider audience-yet another form of politicised compassion.

As these excerpts suggest, when partnerships are intentionally constructed and supported, and when faculty and students enter the brave space partnership offers, that space can become one in which politicised compassion is nurtured. Both faculty and student partners suggest that partnerships argue for and can enact inclusivity (Cook-Sather, 2018a; de Bie et al., 2019), and when students with a diversity of identities experience themselves as "holders and creators of knowledge" (Delgado-Bernal, 2002, p. 106), their efforts can combat neoliberalism, hegemony, exclusion, feminine marginalisation, pity, and narcissism. Not only can partnership counter othering, making students "feel like who I am is more than enough-that my identity, my thoughts, my ideas are significant and valuable" (Cook-Sather \& Agu, 2013, p. 277), it can model, enact, and support a more equitable way of engaging and promote more equitable practices within and beyond the institutions at which it unfolds. Working within existing structures as well as being intentional about the inclusion of a diversity of students (de Bie et al., 2019; Mercer-Mapstone et al., 2019), partnership can promote action toward equity through mobilising politicised compassion.

\section{CONCLUSION}

This paper has engaged in matters of social justice and inclusion and critically considered the academy's positioning of non-traditional or diverse students. We have argued and evidenced that, whilst the HE sector seemingly works for inclusion, it can pathologise those it positions as diverse or "deserving other" without a critical understanding of students' own positions or life experiences. To move forward we have suggested the university needs to become critically familiar with the political histories of students' identities. A more critical and nuanced understanding of students' stories and analyses of their lived experiences is necessary, whether connected to matters of gender, race, disability, sexuality and/or social class alongside an understanding of the affective domain in their learning. Without this understanding the university fails to fully engage with students, thereby contributing to the ways in which they are institutionally positioned and failing to address where social injustices occur and how a deficit model of the "nontraditional" student results in further exclusion.

We see this paper as political, arguing for the consideration of politicised compassion, which we identify as a collaborative student and faculty tool for inclusive pedagogy and action for social justice within and beyond the classroom. Student voices support the idea that a critically considered politicised form of compassion comes from a place that sees where power resides, grasps related matters of habitus, and works to hear student and faculty voices through meaningful forms of pedagogical partnership.

Pedagogical partnership can work to enact this form of politicised compassioncreating the conditions and supporting the work necessary for discerning, naming, and combating inequity. It also creates a space where students can articulate the different 
dimensions of their identities and work with faculty to imagine how the university can create spaces that are welcoming, supportive, and valuing of those differences as resources rather than casting them as deficits to be fixed or managed. The partnership construct can be a space and a process, creating a scaffold for dialogues of politicised compassion and providing a place from which the tangible results of those conversations can push back against the dominant neoliberal flow of divisiveness and destructiveness in education and in wider global society. In sum, we have argued that in the context of failed forms of inclusive education, solidarity can be found amongst faculty and students via the forum of pedagogical partnership. From this forum, politicised compassion can be enabled to encourage practical, well-considered action for social justice and equality.

\section{NOTES ON CONTRIBUTORS}

Suanne Gibson is Associate Head for Teaching and Learning at Plymouth University's Institute of Education and Associate Professor of Education. She has published widely on equality, inclusion and diversity in education and her current focus is on the question of socially just pedagogy and spaces for disabled students in Higher Education.

Alison Cook-Sather is Mary Katharine Woodworth Professor of Education at Bryn Mawr College and Director of the Teaching and Learning Institute at Bryn Mawr and Haverford Colleges. She has published widely on student-faculty partnership, and her current focus is on partnership's potential to address inequities.

\section{REFERENCES}

Agamben, G. 1998. Homer Sacer: Sovereign power and bare life, trans. D. Heller-Roazen. Stanford, CA: Stanford University Press.

Ahmed, S., \& Swain, E. (2006). Doing diversity. Policy Futures in Education, 4(2), 96-100. https://doi.org/10.2304\%2Fpfie.2006.4.2.96

Allan, J. (2015). Waiting for inclusive education? An exploration of conceptual confusions and political struggles. In F. Kiuppis \& R. S. Hausstatter (Eds.), Inclusive education: Twenty years after Salamanaca (pp. 181-190). New York: Peter Lang.

ARC. (2013). Literature review of research into widening participation to higher education. Report to HEFCE and OFFA by ARC Network.

Barnes, C., \& Oliver, M. (2010). Disability studies, disabled people and the struggle for inclusion. British Journal of Sociology of Education, 31(5), 547-560. https://doi.org/10.1080/01425692.2010.500088

Beauchamp-Pryor, K. (2012). From absent to active voices: Securing disability equality within higher education. International Journal of Inclusive Education, 16(3), 283-295. https://doi.org/10.1080/13603116.2010.489120

Bovill, C., (2017). A framework to explore roles within student-staff partnerships in higher education: Which students are partners, when, and in what ways? International Journal for Students as Partners, 1(1). https://doi.org/10.15173/ijsap.v1i1.3062

Bracken, S., \& Novak, K. (Eds.) (2019). Transforming higher education through universal design for learning: An international perspective. Routledge. 
Burke, P. J. (2012). The right to higher education. London: Routledge.

Burke, P. J., Bennett, A., Burgess, C., Gray, K., \& Southgate, E. (2016). Capability, belonging and equity in higher education: Developing inclusive approaches. Centre of Excellence for Equity in Higher Education research report submitted to the National Centre for Student Equity in Higher Education (NCSEHE), Curtin University: Perth. Retrieved from https://www.ncsehe.edu.au/publications/capability-belonging-andequity-in-higher-education-developing-inclusive-approaches/

Cook-Sather, A. (2015). Dialogue across differences of position, perspective, and identity: Reflective practice in/on a student-faculty pedagogical partnership program. Teachers College Record, 117(2).

Cook-Sather, A. (2016). Undergraduate students as partners in new faculty orientation and academic development. International Journal of Academic Development, 21(2), 151162. https://doi.org/10.1080/1360144X.2016.1156543

Cook-Sather, A. (2018a). Developing "Students as Learners and Teachers": Lessons from ten years of pedagogical partnership that strives to foster inclusive and responsive practice. Journal of Educational Innovation, Partnership and Change, 4(1). Retrieved from https://journals.gre.ac.uk/index.php/studentchangeagents/article/view/746

Cook-Sather, A. (2018b). Listening to equity-seeking perspectives: How students' experiences of pedagogical partnership can inform wider discussions of student success. Higher Education Research and Development, 37(5), 923-936. https://doi.org/10.1080/07294360.2018.1457629

Cook-Sather, A. (2019). Respecting voices: How the co-creation of teaching and learning can support academic staff, underrepresented students, and equitable practices. Higher Education, 1-17. https://doi.org/10.1007/s10734-019-00445-w

Cook-Sather, A., \& Agu, P. (2012, October). Students of color and faculty colleagues developing voice in the "counter-spaces" of a professional development program. Paper presented at the Conference of the Professional and Organizational Development Network in Higher Education, Seattle, Washington.

Cook-Sather, A., \& Agu, P. (2013). Students of color and faculty members working together toward culturally sustaining pedagogy. In J. E. Groccia \& L. Cruz (Eds.), To improve the academy: Resources for faculty, instructional, and organizational development (Vol. 32, pp. 271-285). San Francisco: Jossey-Bass.

Cook-Sather, A., Bahti, M., \& Ntem, A. (2019). Pedagogical partnerships: A how-to guide for faculty, students, and academic developers in higher education. Elon University Center for Engaged Teaching Open Access Series.

Cook-Sather, A., Bovill, C., \& Felten, P. (2014). Engaging students as partners in learning and teaching: A guide for faculty. Jossey-Bass, San Francisco.

Cook-Sather, A., Des-Ogugua, C., \& Bahti, M. (2018). Articulating identities and analyzing belonging: A multistep intervention that affirms and informs a diversity of students. Teaching in Higher Education, 23(3), 374-389. https://doi.org/10.1080/13562517.2017.1391201

Cook-Sather, A., \& Felten, P. (2017). Ethics of academic leadership: Guiding learning and teaching. In F. Su, \& M. Wood (Eds.), Cosmopolitan perspectives on academic leadership in higher education (pp. 175-191). London, UK: Bloomsbury. 
Cook-Sather, A., Prasad, S. K., Marquis, E., \& Ntem, A. (2019). Mobilizing a Culture Shift on Campus: Underrepresented Students as Educational Developers. New Directions for Teaching and Learning, 159, 21-30.

Crenshaw, K. (1991). Mapping the margins: Intersectionality, identity politics, and violence against women of color. Stanford Law Review, 43(6), 1241-1299. https://doi.org/10.2307/1229039

de Bie, A., Marquis, E., Cook-Sather, A., \& Luqueño, L. P. (2019). Promoting equity and inclusion through pedagogical partnership. Manuscript in preparation.

de Bie, A., Marquis, E., Cook-Sather, A., \& Luqueño, L. P. (2019). Valuing knowledge(s) and cultivating confidence: Contributing to epistemic justice via student-faculty pedagogical partnerships. In J. Hoffman, P. Blessinger, \& Makhanya, M. (Eds.), Strategies for fostering inclusive classrooms in higher education: International perspectives on equity and inclusion. Innovations in Higher Education Teaching and Learning (Vol. 16, pp. 35-48). Emerald Publishing Limited. https://doi.org/10.1108/S2055-364120190000016004

Delgado Bernal, D. (2002). Critical race theory, Latino critical theory, and critical racedgendered epistemologies: Recognizing students of color as holders and creators of knowledge. Qualitative Inquiry, 8(1), 105-126. https://doi.org/10.1177\%2F107780040200800107

Department for Education and Skills. (2003). The future of higher education. London, HMSO.

Department for Education and Skills. (2004). Higher education act. London, HMSO.

Fielding, M. (1999). Radical collegiality: Affirming teaching as an inclusive professional practice. Australian Educational Researcher, 26(2), 1-34. https://doi.org/10.1007/BF03219692

Fleras, A. (2011). Cooling out troublesome constituents: The politics of managing 'isms' in the antipodes. In R. Hasmath (Ed.), Managing ethnic diversity: Meanings and practices from an international perspective. Farnham, Surrey: Ashgate.

Gale, T., \& Hodge, S. (2014). Just imaginary: Delimiting social inclusion in higher education. British Journal of Sociology of Education, 35(5), 688-709. https://doi.org/10.1080/01425692.2014.919841

Gibson, S. (2006). Beyond a "culture of silence": Inclusive education and the liberation of "voice." Disability and Society, 21(4).

Gibson, S. (2012). Narrative accounts of university education: Socio-cultural perspectives of students with disabilities. Disability and Society, 27(3), 353-369. https://doi.org/10.1080/09687599.2012.654987

Gibson, S. (2015). When rights are not enough: What is? Moving towards new pedagogy for inclusive education within UK universities. International Journal of Inclusive Education, 19(8), 875-886. https://doi.org/10.1080/13603116.2015.1015177

Gibson, S. \& Baskerville, D. (Eds.) (2017). The politics of care, compassion and concern in the contemporary academy [Special issue]. Pastoral Care in Education, 35(3).

Gibson, S., Baskerville, D., Berry, A., Black, A., Norris, K., \& Symeonidou, S. (2016). 'Diversity' 'widening participation' and 'inclusion' in higher education: An international study. Journal of Widening Participation and Lifelong Learning, 18(3), 7-33. https://doi.org/10.5456/WPLL.18.3.7

Gibson, S., Baskerville, D., Berry, A., Black, A., Norris, K., \& Symeonidou, S. (2017). Including students as co-enquirers: Matters of identity, agency, language and labelling in an 
International participatory research study, International Journal of Educational Research, 81, 108-118. https://doi.org/10.1016/i.ijer.2016.11.008

Gibson, S., Grace, A., O'Sullivan, C., \& Pritchard, C. (2018). Exploring transitions into the undergraduate University world using a student-centred framework. Teaching in Higher Education, 24(7), 819-833. https://doi.org/10.1080/13562517.2018.1511538

Gibson, S., \& Kendall, L. (2010). Stories from school: Dyslexia and learners' voices on factors impacting on achievement. Support for Learning, 25(4), 187-193. https://doi.org/10.1111/j.1467-9604.2010.01465.x

Giroux, H. (2010). Bare pedagogy and the scourge of neoliberalism: Rethinking higher education as a democratic public sphere. The Educational Forum, 74(3), 184-196. https://doi.org/10.1080/00131725.2010.483897

Gross, C., Gottburgsen, A., \& Phoenix, A. (2016). Education systems and intersectionality. In A. Hadjar \& C. Gross (Eds.), Education systems and inequalities: International comparisons (pp. 15-72). Bristol: Policy Press.

Grummell, B., Devine, D., \& Lynch, K. (2009). The care-less manager: Gender, care and new managerialism in higher education. Gender and Education, 21(2), 191-208. https://doi.org/10.1080/09540250802392273

Healey, M., Flint, A., \& Harrington, K. (2014). Engagement through partnership: Students as partners in learning and teaching in higher education. Higher Education Academy, York. Retrieved from https://www.advance-he.ac.uk/knowledge-hub/engagementthrough-partnership-students-partners-learning-and-teaching-higher

Healey, R. L., Lerczak, A., Welsh, K., \& France, D. (2019). By any other name? The impacts of differing assumptions, expectations, and misconceptions in bringing about resistance to staff-student partnership. International Journal for Students as Partners, 3(1). https://doi.org/10.15173/ijsap.v3i1.3550

Hockings, C. (2010). Inclusive learning and teaching in HE: A synthesis of research. Higher Education Academy. Retrieved from https://www.advance-he.ac.uk/knowledgehub/inclusive-learning-and-teaching-higher-education-synthesis-research

Hughes, K. (2015). The social inclusion meme in higher education: Are universities doing enough? International Journal of Inclusive Education, 19(3), 303-31. https://doi.org/10.1080/13603116.2014.930518

Jack, A. A. (2019). The privileged poor: How elite colleges are failing disadvantaged students. Cambridge, MA: Harvard University Press.

Jaschick, S. (2016, November 14). Tensions, protests, incidents. Inside Higher Ed. Retrieved from https://www.insidehighered.com/news/2016/11/14/protests-and-incidentsspread-following-trump-election-victory

Liasidou, A. (2014). Critical disability studies and socially just change in higher education. British Journal of Special Education, 41(2), 120-135. https://doi.org/10.1111/14678578.12063

Lynch, K. (2010). Carelessness: A hidden doxa of higher education, arts and humanities. Higher Education, 9(1), 54-67. https://doi.org/10.1177\%2F1474022209350104

Madriaga, M. (2007). Enduring disablism: Students with dyslexia and their pathways into UK higher education and beyond. Disability and Society, 22(4), 399-412. https://doi.org/10.1080/09687590701337942 
Madriaga, M., Hanson, K., Kay, H., \& Walker, A. (2011). Marking-out normalcy and disability in higher education. British Journal Special Education, 32(6), 901-920. https://doi.org/10.1080/01425692.2011.596380

Mann, S. J. (2001). Alternative perspectives on the student experience: Alienation and engagement. Studies in Higher Education, 26(1), 7-19. https://doi.org/10.1080/03075070020030689

Marquis, E., Jayaratnam, A., Mishra, A., \& Rybkina, K. (2018). "I feel like some students are better connected": Students' perspectives on applying for extracurricular partnership opportunities. International Journal for Students as Partners, 2(1), 64-81. https://doi.org/10.15173/ijsap.v2i1.3300

Matthews, K. E. (2017). Five propositions for genuine students as partners practice. International Journal for Students as Partners, 1(2). https://doi.org/10.15173/ijsap.v1i2.3315

Matthews, K. E., Cook-Sather, A., Acai, A., Dvorakova, S. L., Felten, P., Marquis, E., \& MercerMapstone, L. (2019). Toward theories of partnership praxis: An analysis of interpretive framing in literature on students as partners in university teaching and learning. Higher Education Research \& Development, 38(2). https://doi.org/10.1080/07294360.2018.1530199

Mercer-Mapstone, L., Islam, M., \& Reid, T. (2019). Are we just engaging 'the usual suspects'? Challenges in and practical strategies for supporting equity and diversity in studentstaff partnership initiatives. Teaching in Higher Education. https://doi.org/10.1080/13562517.2019.1655396

Mutch, C., \& Tatebe, J. (2017). From collusion to collective compassion: Putting heart back into the neoliberal university. Pastoral Care in Education, 35(3), 221-234. https://doi.org/10.1080/02643944.2017.1363814

Nash, J. C. (2008). Rethinking intersectionality. Feminist Review, 89, 1-15. https://doi.org/10.1057\%2Ffr.2008.4

New, J. (2016, February 11). Get ready for more protests. Inside Higher Ed. Retrieved from https://www.insidehighered.com/news/2016/02/11/survey-finds-nearly-1-10freshmen-plan-participating-campus-protests

Oliver, M. \& Zarb, G. (1989). The politics of disability: A new approach. Disability and Society, 4(3), 221-239. https://doi.org/10.1080/02674648966780261

Perez, K. (2016). Striving toward a space for equity and inclusion in physics classrooms. Teaching and Learning Together in Higher Education, 18. https://repository.brynmawr.edu/tlthe/vol1/iss18/3

Quinn, J. (2013). Drop-out and completion in higher education in Europe among students from under-represented groups. (Report of the Network of Experts on Social Aspects of Education and Training [NESET]). Retrieved from https://nesetweb.eu/en/resources/library/drop-out-and-completion-in-highereducation-in-europe-among-students-from-under-represented-groups/

Rashedi, R., Plante, T. G., \& Callister, E. S. (2015). Compassion development in higher education. Journal of Psychology and Theology, 43(2), 131-139. https://doi.org/10.1177\%2F009164711504300205

Slee, R. (2008). Beyond special and regular schooling? An inclusive education reform agenda. International Studies in Sociology of Education, 18(2), 99-116. https://doi.org/10.1080/09620210802351342 
Solórzano, D., Ceja, M., \& Yosso, T. (2000). Critical race theory, racial microaggressions, and campus racial climate: The experiences of African American college students. The Journal of Negro Education, 69(1/2), 60-73.

U.S. Department of Education, Office of Planning, Evaluation and Policy Development and Office of the Under Secretary. (2016). Advancing diversity and inclusion in higher education. Washington, D.C.

http://www2.ed.gov/rschstat/research/pubs/advancing-diversity-inclusion.pdf.

Volk, S. (2017, April 24). New student activism: Stops on the road to new solidarities [Blog post]. Teaching and Learning at Oberlin College. Center for Teaching Innovation and Excellence, Oberline College. Retrieved from http://languages.oberlin.edu/blogs/ctie/2017/04/23/new-student-activism-stopson-the-road-to-new-solidarities/

Walker, M. (2010). Pedagogy for rich human being-ness in global times. In Unterhalter, E. \& Carpentier, V. (Eds.), Global inequalities and higher education (pp. 219-240). London: Palgrave Macmillan.

Warwick, P. (2016). Education for sustainable development: A movement towards pedagogies of civic compassion. FORUM, 58(3), 407-414. https://doi.org/10.15730/forum.2016.58.3.407

Zembylas, M. (2013). The "crisis of pity" and the radicalization of solidarity: Toward critical pedagogies of compassion. Educational Studies, 49(6), 504-52. https://doi.org/10.1080/00131946.2013.844148

Zembylas, M., Bozalek, V., \& Shefer, T. (2014). Tronto's notion of privileged irresponsibility and the reconceptualisation of care: Implications for critical pedagogies of emotion in higher education. Gender and Education, 26(3), 200-214. https://doi.org/10.1080/09540253.2014.901718 